\title{
$\beta$-Glucosidase Recovery from a Solid-State Fermentation System by Aspergillus niger
}

\author{
M. Subhosh Chandra ${ }^{1,2}$, B. Rajasekhar Reddy ${ }^{1}$ and Yong Lark Choi ${ }^{3} \star *$ \\ ${ }^{1}$ Department of Microbiology, Sri Krishnadevaraya University, Anantapur 515-003, India \\ ${ }^{2}$ Present Address:Department of Microbiology, Yogi Vemana University, Kadapa 516-003, India \\ ${ }^{3}$ Department of Biotechnology, College of Natural Resources and Life Science, Dong-a University, Busan 604714, Korea
}

Received April 17, 2010 /Accepted May 15, 2010

\begin{abstract}
Investigations were carried out on a $\beta$-glucosidase produced by Aspergillus niger under solid-state fermentation conditions as a model of enzyme recovery from fermented wheat bran. The leaching efficiency of distilled water to recover the enzyme from the fermented bran was higher than acetate buffer, citrate buffer, citrate-phosphate buffer and 5\% methanol; thus, the conditions were further optimized with distilled water as the extracting agent. After fermented bran was washed three times with distilled water for $1.5 \mathrm{hr}$ each under shaking conditions at 1:5 solid to solvent ratio, a maximum recovery of $0.025 \mathrm{U} / \mathrm{g}$ of wheat bran was obtained.
\end{abstract}

Key words : $\beta$-Glucosidase, wheat bran, solid-state fermentation, Aspergillus niger, recovery

\section{Introduction}

Microbial enzymes are produced by using either submerged fermentation (SF) or solid-state fermentation (SSF) techniques [34]. Solid-state fermentation processes have been developed for fungal enzyme production at industrial scale [23]. SSF technology has gained renewed attention from industry because it has become a more attractive alternative to submerged fermentation for many productions [4]. Thus, SSF is found to produce a more stable product, with less energy requirements and simple technology and smaller volumes of polluting effluents [22]. Additionally, SSF prevents catabolite repression phenomena that adversely influence the production of many microbial products [28]. Outstanding to the information that SSF may be useful means, especially in the case of some industrial enzymes, a renewed interest in this technology became evident in the last few years [24]. However, on downstream processing of SSF-produced enzymes information is very scanty, even though its significant role and economic implications are well known [11].

The presence of the product in concentrated form [25] and the consequent decreased cost of down-stream processing as well as waste obviating the need for waste treatment [24]

\footnotetext{
*Corresponding author

Tel : +91-8554-255759, Fax : +91-8554-241910

E-mail : rajasekhar_bontha@yahoo.co.in

${ }^{* *}$ Corresponding author

Tel : +82-51-200-7585, Fax : +82-51-200-6536

E-mail : ylchoi@dau.ac.kr
}

are the major reasons which explain the growing interest in solid state fermentation processes [12]. Depending upon its application on process economics and to reduce further down-stream processing costs, various techniques have been developed by the researchers [2,3]. The efficient solvent to leach enzyme from microorganism substrate may depend on many factors e.g. type of enzyme, source of enzymes and substrates used as a medium.

The economy of the process is severely affected by the high cost of water removal and the low added value of the product, which make it mandatory to recover and market the cellulolytic enzymes produced [15]. Although enzymatic saccharification of cellulose has been demonstrated to be uneconomical, large quantities of active and cheap cellulase preparations are required [26]. To overcome this short-coming, efforts are being directed continuously to reduce the cost of production of cellulase by searching high-yielding cellulase producing strains, mutants that are resistant to catabolite repression, genetic engineering methods and optimizing processes of fermentation methods [18].

$\beta$-Glucosidases have been the subject of a great extent recent research due to their potential for many bio-technological and industrial applications in food products, essential oils, pulp and paper, jams, juices, biomass conversion and pollution control $[8,37]$. These enzymes can be recovered rather easily from SSF, making this system extremely appropriate for protein enrichment and cellulase production from lignocellulosics [17]. Extraction of enzyme from the fer- 
mented bran is an important unit operation in SSF [4,22]. Until now, cellulolytic enzymes have been extracted with different solvents without systematic procedure [33]. In this connection, the present study addressed the extraction of $\beta$ -glucosidase (EC 3.2.1.21), one of the components of the cellulase complex, as a model enzyme produced by Aspergillus niger in SSF.

\section{Materials and Methods}

\section{Culture and inoculum preparation}

A local isolate of Aspergillus niger isolated from the soils contaminated with the effluents of cotton ginning mills in Nandyal, India [30] was used in the present study. The fungal culture was maintained on a Czapek Dox medium. The spore suspension of $A$. niger was prepared by adding $2 \mathrm{ml}$ of sterile distilled water to the 7-day grown slants.

\section{Fermentation method}

The fermentation was carried out in $250 \mathrm{ml}$ Erlenmeyer flasks. Six milliliters of the modified Czapek Dox medium was added to the $10 \mathrm{~g}$ wheat bran in the flasks at the beginning, and the remaining balance for achieving $40 \%$ moisture level was provided to the respective matrix in the form of distilled water. The modified Czapek Dox liquid medium contained (g/l) $2.0 \mathrm{~g} \mathrm{NaNO}_{3}, 1.0 \mathrm{~g} \mathrm{~K}_{2} \mathrm{HPO}_{4}, 0.5 \mathrm{~g} \mathrm{MgSO}_{4}$ - $7 \mathrm{H}_{2} \mathrm{O}, 0.5 \mathrm{~g} \mathrm{KCl}, 0.01 \mathrm{~g} \mathrm{FeSO}_{4} \cdot 7 \mathrm{H}_{2} \mathrm{O}, 30.0 \mathrm{~g}$ sucrose, 25.0 $\mathrm{g}\left(\mathrm{NH}_{4}\right)_{2} \mathrm{SO}_{4}$ and $5.0 \mathrm{~g}$ cellulose. Flasks were autoclaved for $30 \mathrm{~min}$ at $121^{\circ} \mathrm{C}$ and inoculated with spores at $2 \times 10^{6}$, followed by incubation at ambient $\left(30 \pm 2^{\circ} \mathrm{C}\right)$ temperature. At regular intervals, sterile distilled water was added to each flask to maintain the initial moisture content during incubation [6].

\section{Extraction of enzyme}

Ten grams of the fermented bran in a $250 \mathrm{ml}$ conical flask was extracted with the selected solvents by soaking the fermented bran at $30^{\circ} \mathrm{C}$ for 30 to $150 \mathrm{~min}$. The crude extract was then filtered through a cotton cloth and the filtrate was centrifuged at 9,000× $g$ for $20 \mathrm{~min}$. The clear filtrate obtained was used for the $\beta$-glucosidase assay. The parameters selected for this study were type of solvent, volume of solvent, soaking time, physical state of leaching and number of washes. In the experiment on the parameter pertaining to the number of washings, fresh lots of the solvent were added to the fermented bran recovered at the end of the previous extraction. Leachates from these extractions were collected separately and tested for the recovery of $\beta$ - glucosidase.

\section{Enzyme assay}

Flasks were withdrawn daily for 5 days. Activity of $\beta$ -glucosidase activity in the culture filtrate was determined according to the method of Herr [14]. One unit of $\beta$-glucosidase activity was defined as the amount of enzyme liberating $1 \mu$ mole of pnitrophenol per min under standard assay conditions. The production of the enzyme on solid matrix is expressed as the number of units per gram of bran.

\section{Statistical analysis}

All measured values are the averages of three replicates. Values in the figures are means of 3 replicates \pm standard deviation.

\section{Results}

\section{Selection of solvent}

The first step for obtaining $\beta$-glucosidase from the fermented bran is leaching, a process devoted to recovery of the enzyme from solids in order to obtain a crude extract using an appropriate solvent $[4,11]$. In order to find out an efficient solvent for maximal recovery of $\beta$-glucosidase from the fermented bran, we have scrutinized different solvents such as distilled water, $0.2 \mathrm{M}$ acetate buffer ( $\mathrm{pH}$ 5.0), $0.2 \mathrm{M}$ citrate buffer ( $\mathrm{pH}$ 5.0), 0.2 M citrate-phosphate buffer (pH 5.0) and 5\% methanol (v/v) (Fig. 1). A single wash with $20 \mathrm{ml}$ distilled water was used for extraction because, among the solvents used, the maximum extraction of enzyme $(0.0158 \mathrm{U} / \mathrm{g})$ was achieved with distilled water from fermented bran. Therefore, subsequent optimization experiments were carried out with only distilled water as the extracting agent.

\section{Solid to solvent ratio}

In SSF system, solvent is used a smaller amount. Thus, a sufficient amount of solvent is required to leach out the enzyme from the fermented bran. The volume of the solvent i.e. distilled water used within a range of $10-50 \mathrm{ml}$ and recovery of enzyme was carried out immediately after addition of solvent. The extraction results are presented in Fig. 2. The solid to solvent ratio $1: 5$ i.e. $50 \mathrm{ml}$ of distilled water was recovered maximal enzyme from the $10 \mathrm{~g}$ of fermented bran. The enzyme activity decreased when the lower volume of 


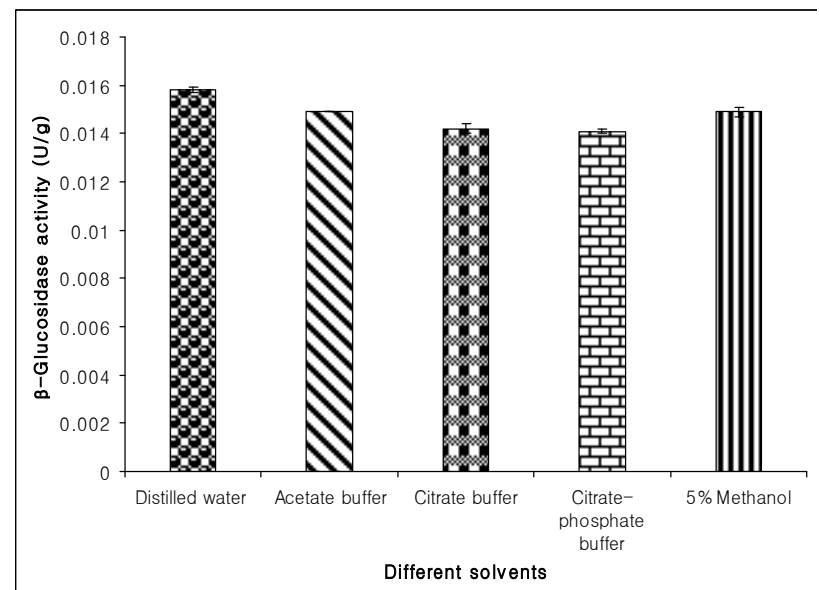

Fig. 1. Effect of different solvents on $\beta$-glucosidase extraction. Values in the figure are means of 3 replicates with standard deviation (SD).

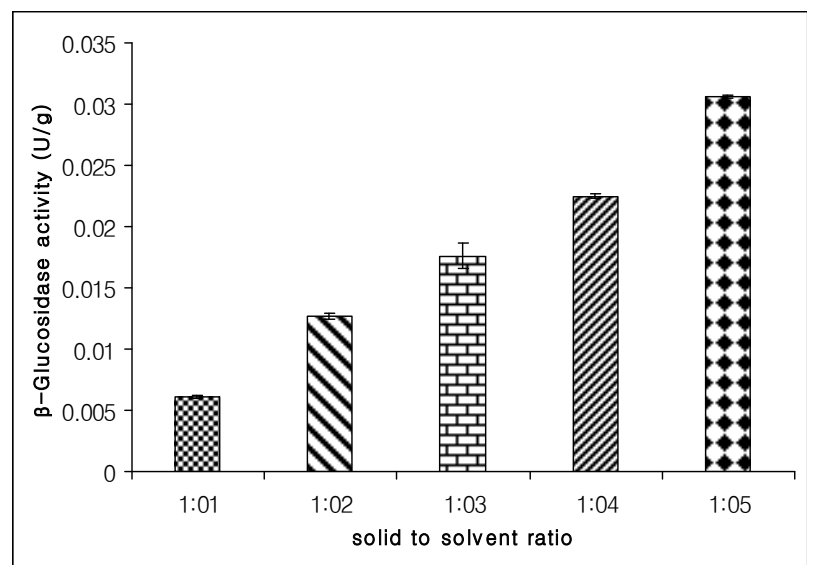

Fig. 2. Effect of solvent volume on $\beta$-glucosidase extraction. Values in the figure are means of 3 replicates with standard deviation (SD).

the solvents used for extraction.

\section{Incubation time for soaking}

The volume of the water in relation to the solid substrate was retained at the optimal level, and the incubation for soaking was further optimized for maximum recovery of enzyme from the fermented bran. The incubation time was varied from 30-150 min (Fig. 3). Ninety minutes soaking time was recovered maximum enzyme, beyond that the recovery of enzyme from the fermented bran decreased.

\section{Physical state of leaching}

Two leaching conditions such as stationary and shaking were employed during the extraction of enzyme from the fermented bran using water. Shaking conditions were

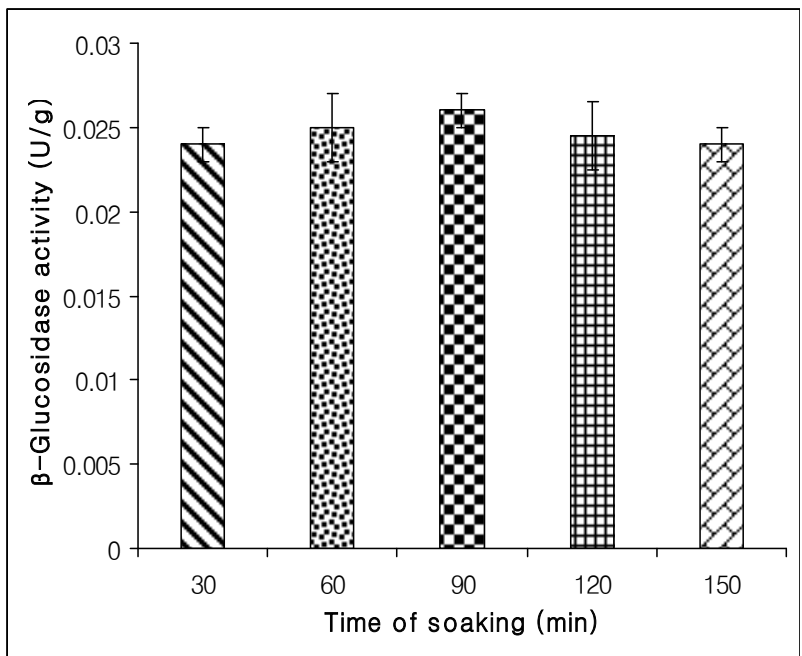

Fig. 3. Effect of soaking time on $\beta$-glucosidase extraction. Values in the figure are means of 3 replicates with standard deviation (SD).

attained by adding the mixture of fermented bran and solvent in the flasks and placing them on an orbital shaker at $150 \mathrm{rpm}$ at $30^{\circ} \mathrm{C}$. Physical state of leaching didn't have influence on extraction of $\beta$-glucosidase from fermented bran (Fig. 4). Extraction of $\beta$-glucosidase from the fermented bran occurred to the same extent under both conditions.

\section{Number of washes}

In the earlier experiments, leaching of $\beta$-glucosidase from fermented bran was carried out with a single wash of the solvent. In order to find out whether a single wash could completely recover the enzyme, fermented bran collected from the previous extraction was extracted again with the fresh lots of solvent in repeated manner for recovery of

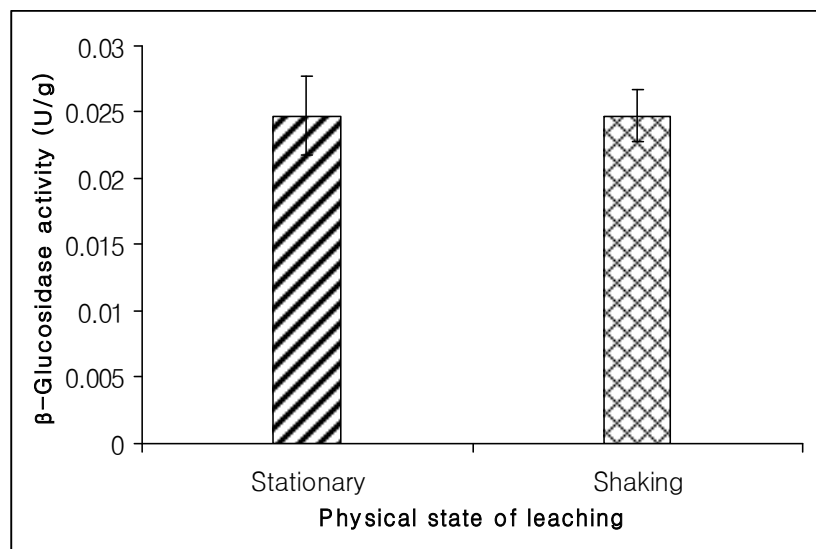

Fig. 4. Effect of physical state of leaching on $\beta$-glucosidase extraction. Values in the figure are means of 3 replicates with standard deviation (SD). 


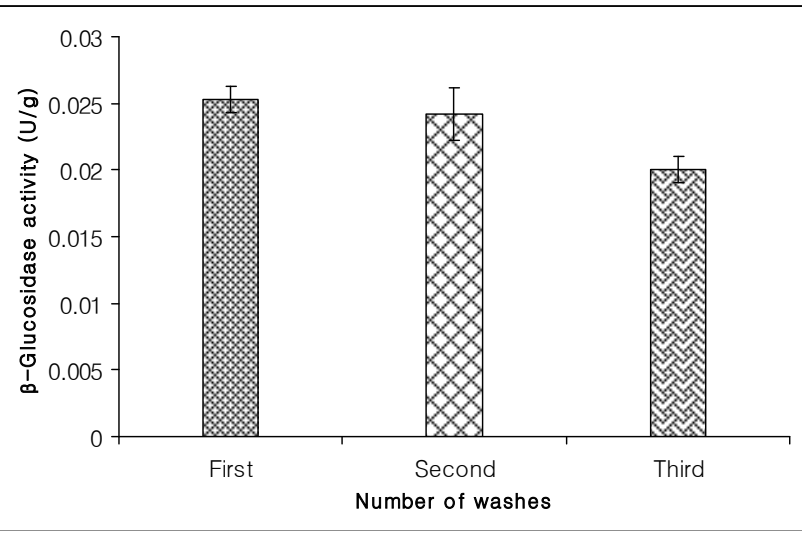

Fig. 5. Effect of number of washes on $\beta$-glucosidase extraction. Values in the figure are means of 3 replicates with standard deviation (SD).

enzyme. The enzyme was recovered in large amounts from the first two washings, third washing leached less amount of enzyme indicating two washings were sufficient for maximum leaching of the enzyme (Fig. 5).

\section{Discussion}

At the end of the fermentation, when the product is at its maximum level, the fermentation bran is subjected to down stream processing. The compost extract was capable of releasing reducing sugars from wheat straw, suggesting a possible biotechnological role for this extract in the upgrading of waste straw to animal fodder [27]. The cellulolytic enzymes were extracted from the fermented beet pulp with $0.1 \mathrm{M}$ sodium acetate buffer, $\mathrm{pH} 5.0$ (10 volumes/g pulp) under shaking conditions at room temperature [9]. Citrate buffer $(0.1 \mathrm{M}, \mathrm{pH} 4.8)$ was tried to leach cellulase from the fermented bran [10]. Extraction with fifty millilitre of sodium citrate buffer ( $50 \mathrm{mM}, \mathrm{pH}$ 6.0) showed good results under mild shaking for recovery of cellulolytic enzymes [1]. Phosphate buffer (0.01 M, pH 7.0) was used to extract cellulases from fermented banana wastes by bacteria [19]. Tween - 80 is frequently used for extraction of different enzymes. The efficiency of leaching increased as the ratio of solvent-to-solid increased [22]. The cellulases and hemicellulases were extracted by suspending the fermented corn stover in distilled water with shaking for $1 \mathrm{hr}$ at $25^{\circ} \mathrm{C}$ [32]. For optimal recovery of cellulases the fermented bran were mixed with 10-25 $\mathrm{ml}$ of distilled water under shaking condition at 100-130 rpm for one hour [29,36]. Similarly, distilled water was employed, as extracting solvent for leaching of endoglucanase, FPase, cellulases and xylanases from the fermented bran $[5,13,16]$.

The ratio of solvent-to-solid plays a significant role in the extraction of enzyme from the fermented bran. Recovery of the low yield of enzyme from the fermented bran with lower volume of solvent might be due to the inadequate solvent volume to penetrate the fermented substrate [5]. Higher solvent to solid ratios also causes the solute to be more dilute in the final extract. The increase in leaching efficiency gained at higher ratios must, therefore, be balanced against the extra effort for concentration of the dilute extract. However, in many cases, it may not be possible to achieve an economic balance [22]. Virtually, information on influence of solvent to solid ratio on extraction of cellulase from fermented bran is lacking. For extraction of cellulases, distilled water at the ratio of 1:20 (w/v) was used [16]. The enzyme from fermented banana fruit stalk medium was extracted twice with $0.01 \mathrm{M}$ phosphate buffer ( $\mathrm{pH}$ 7.0) applying a substrate and buffer ratio of 1:10 using a simple contact method [20]. The extent of recovery of other enzymes such as amylase, amyloglucosidase and protease was assessed by varying the volume of solvent [7,35]. An increase in solvent to solid ratio from 2:1 to 9:1 improved the efficiency of leaching of a -amylase from 41 to $100 \%$ [35]. The increase or decrease in solvent to solid ratio could affect activity of enzymes [7]. Hence, in order to have the product in concentrated form, it is always preferable to use low bran to solvent with highest leaching efficiency. In the present study, $50 \mathrm{ml}$ volume of the solvent water for $10 \mathrm{~g}$ of fermented bran was optimal to leach $\beta$-glucosidase. Similarly, solid to solvent ratio (1:5) was employed for extraction of FPase [5].

Solid to solvent contact time is another important parameter for recovery of enzyme. In the present investigation 90 min contact time between solid to solvent recovered maximum $\beta$-glucosidase. At higher contact time the $\beta$ -glucosidase recovery yield was low, this may be due to the inactivation of enzyme. The maximal recovery of FPase at $90 \mathrm{~min}$ solid to solvent contact time was reported [4]. Soaking of the moldy substrate in water at room temperature $\left(25\right.$ to $\left.28^{\circ} \mathrm{C}\right)$ for $1 \mathrm{hr}$ was used for the recovery of cellulases and $\beta$-glucosidase [1,31]. With $150 \mathrm{~min}$ occasional agitation for the leaching of a-galactosidase from the fermented bran, soaking for amylase extraction was reported [31].

Influence of physical state of leaching on extraction and recovery of $\beta$-glucosidase from fermented bran was not systematically examined. Soaking of fermented corn stover, 
Eichhornia leaves, coconut coir pith and rice straw in distilled water with shaking for $1 \mathrm{hr}$ was employed for extraction of cellulose $[1,29,32,36]$. Soaking of fermented bran with distilled water without shaking for $1 \mathrm{hr}$ was employed for extraction of cellulose [16]. In the present study, two methods of leaching stationary and shaking were compared on extraction of $\beta$-glucosidase from the fermented bran. Both the conditions were recovered same yield of $\beta$-glucosidase. In earlier studies made, one hour duration was employed for leaching of cellulase enzyme from fermented bran $[1,16,29,32,36]$. Results of the present study indicate that 90 min duration is sufficient for the extraction of $\beta$-glucosidase.

\section{Conclusion}

There is no study on $\beta$-glucosidase extraction from fermented bran by Aspergillus niger. Therefore an attempt was made in the present study to optimize the extraction methods of $\beta$-glucosidase from fermented bran. The present investigation showed that the distilled water with three washes for $90 \mathrm{~min}$ at solvent to solid ratio of $5 \mathrm{ml}$ distilled water to $1 \mathrm{~g}$ of wheat bran resulted in the optimal extraction of $\beta$-glucosidase from the fermented bran.

\section{Acknowledgement}

This work was supported by the Dong-A University research fund.

\section{References}

1. Badhan, A. K., B. S. Chadha, J. Kaur, H. S. Saini, and M. K. Bhat. 2007. Production of multiple xylanolytic and cellulolytic enzymes by thermophilic fungus Myceliophthora sp. IMI 387099. Bioresource Technol. 98, 504-510.

2. Caltron, G. J., C. S. Coobs, and J. P. Hmman. 1986. Manual of Industrial Microbiology and Biotechnology, American society of microbiology, Washington. USA, 436-445.

3. Castilho, L. R., T. L. M. Alves, and A. M. Ricardo. 1999. A Recovery of pectolytic enzymes produced by solid state culture of Aspergillus niger. Process Biochem 34, 181-186.

4. Chandra, M. S., B. R. Reddy, and Y. L. Choi. 2008. Production of cellulolytic enzymes by Aspergillus niger on solid and submerged state fermentation. J. Life Sci. 18, 1049-1052.

5. Chandra, M. S., B. R. Reddy, and Y. L. Choi. 2008a. Optimization of extraction of filter paperase from the fermented bran of Aspergillus niger in solid state fermentation. J. Appl. Biol. Chem 51, 155-159.
6. Chandra, M. S., B. Viswanath, and B. R. Reddy. 2007. Cellulolytic enzymes on lignocellulosic substrates in solid state fermentation by Aspergillus niger. Indian J. Microbiol. 47, 323-328.

7. Chundakhadu, K. 1999. Production of bacterial cellulases by solid state bioprocessing of banana wastes. Bioresource Technol. 69, 231-239.

8. Cihangir, N. and E. Sarikaya. 2004. Investigation of lipase production by a new isolate of Aspergillus sp. World J. Microbiol. Biotechnol. 20, 193-197.

9. Considine, P. J., A. O'Rorke, T. J. Hackett, and M. P. Coughlan. 1988. Hydrolysis of beet pulp polysaccharides by extracts of solid state cultures of Penicillium capsulatum Biotechnol. Bioeng. 31, 433-438.

10. Fadel, M. 2000. Production physiology of cellulases and $\beta$ -glucosidase enzymes of Aspergillus niger grown under solid state fermentation conditions. J. Biol. Sci. 1, 401-411.

11. Fernandez Lahore, H. M., E. R. Fraile, and O. Cascone. 1998. A protease recovery from a solid-state fermentation system. J. Biotechnol. 62, 83-93.

12. Hahn-Hagerdal, B. 1986. Enzyme Microbiol. Technol. 8, 322.

13. Heck, J. X., P. F. Hertz, and M. A. Z. Ayub. 2002. Cellulase and xylanase production by isolated Amazon Bacillus strains using soybean industrial residue based solid state cultivation. Braz. J. Microbiol. 33, 213-218.

14. Herr, D. 1979. Secretion of cellulases and $\beta$-glucosidase by Trichoderma viride TTCC 1433 in submerged cultures on different substrates. Biotechnol. Bioeng. 21,1361-1363.

15. Illanes, A., G. Aroca, L. Cabello, and F. Acevedo. 1992. World J. Microbiol. Biotechnol. 8, 488-493.

16. Jecu, L. 2000. Solid state fermentation of agricultural wastes for endoglucanase production. Ind Crop. Prod 11, 1-5.

17. Kim, J. H., M. Hosobuchi, M. Kishimoto, T. Seki, T. Yoshida, H. Taguchi, and D. D. Y. Ryu. 1985. Cellulase production by a solid state culture system. Biotechnol. Bioeng. 27, 1445-1450.

18. Kotchoni, O. S. and O. O. Shonukan. 2002. Regulatory mutations affecting the synthesis of cellulase in B. pumulis. World J. Microbiol. Biotechnol. 18, 487-491.

19. Krishna, C. 1999. Production of bacterial cellulases by solid state bioprocessing of banana wastes. Bioresource Technol. 69, 231-239.

20. Krishna, C. and M. Chandrasekharan. 1996. Banana waste as substrate for a-amylase production by Bacillus subtilis (CBTK 106) under solid state fermentation. Appl. Microbiol. Biotechnol. 46, 106-111.

21. Leda, R. C., A. M. Ricardo, and L. M. A. Tito. 2000. Production and extraction of pectinases obtained by solid state fermentation of agroindustrial residues with Aspergillus niger. Bioresource Technol. 71, 45-50.

22. Lonsane, B. K. and M. M. Krishnaiah. 1992. Product leaching and downstream processing, pp. 147, In Solid Substrate Cultivation, In Doelle, H. W., D. A. Mitchell, and C. E. Rolz, (eds.), Elsevier Science Publishers. London.

23. Lonsane, B. K. and M. V. Ramesh. 1990. Production of bacterial thermostable a-amylase by solid state fermentation: a 
potential tool for achieving economy in enzyme production and starch hydrolysis. Advances Appl. Microbiol. 35, 1-56.

24. Lonsane, B. K. and N. P. Ghildyal. 1992. Exoenzymes, pp. 191-209, In Doelle, H. W., D. A. Mitchell, and C. E. Rolz (eds.), Solid Substrate Cultivation. Elsevier, London.

25. Lonsane, B. K., N. P. Ghild, S. Budeatman, and S. V. Ramakrishna. 1985. Engineering aspects of solid state fermentation. Enzyme Microb. Technol. 7, 258-265.

26. Lynd, L. R., P. J. Weimer, W. H. Van Zyl, and I. S. Pretorius. 2002. Microbial cellulose utilization: Fundamentals and biotechnology. Microbiol. Mole. Biol. Rev. 66, 506-577.

27. McCarthy, A. J. 1987. Lignocellulose-degrading actinomycetes. FEMS Microbiol. Rev. 46, 145-163.

28. Mitchell, D. A., Z. Targonski, A. Rogalski, and A. Leonowicz. 1992. Substrates for processes, pp. 29-52, In Doelle, H. W., D. A. Mitchell, and C. E. Rolz (eds.), Solid Substrate Cultivation. Elsevier, London,

29. Muniswaran, P. K. A. and N. C. L. N. Charyulu. 1994. Solid substrate fermentation of coconut coir pitch for cellulase production. Enzyme Microb. Technol. 16, 436-440.

30. Narasimha, G., G. V. A. K. Babu, and B. Rajasekhar Reddy. 1999. Cellulolytic activity of fungal cultures isolated from soil contaminated with effluents of cotton ginning industry.
J. Environ. Biol. 20, 235-239.

31. Palit, S. and R. Banerjee. 2001. Optimization of extraction parameters for recovery of a-amylase from the fermented bran of Bacillus circulans GRS313. Braz. Arch Biol. Technol. 44, 107-111.

32. Panagiotou, G., D. Kekos, B. J. Macris, and P. Christakopoulos. 2003. Production of cellulolytic and xylanolytic enzymes by Fusarium oxysporum grown on corn stover in solid state fermentation. Ind Crop. Prod 18, 37-45.

33. Ramakrishna, S. V., T. Suseela, N. P. Ghildyal, S. A. Jaleel, P. Prema, B. K. Lonsane, and S. Y. Ahmed. 1982. Recovery of amyloglucosidase from moldy bran. Ind J. Technol. 20, 476-480

34. Ramamurthy, V. and R. M. Kothari. 1993. Comparison of fungal protease production by submerged and surface cultivation. J. Biotechnol. 27, 349-354.

35. Ramesh, M. V. and B. K. Lonsane. 1988. Chem Mikrobiol. Technol. Lebnsm 11, 155.

36. Singh, J. and A. P. Garg. 1995. Production of cellulases by Gliocladium virens Miller et al. on Eichhornia under solid state fermentation conditions. J. Ind Bot. Soc. 74, 305-309.

37. Tolan, J. S. and B. Foody. 1999. Cellulase from submerged fermentation. AdV. Biochem Eng. Biotechnol. 65, 41-67.

\section{초록 : Aspergillus niger의 고체상태 발효 시스템에서의 $\beta$-Glucosidase 회수 \\ 수보쉬 찬드라 ${ }^{1,2} \cdot$ 라자세카 레디 ${ }^{1} \cdot$ 최용락 ${ }^{3}{ }^{*}$ \\ ('Sri Krishnadevaraya 대학교 미생물학과, ${ }^{2}$ Yogi Vemana 대학교 미생물학과, ${ }^{3}$ 동아대학교 생명공학과))}

밀기울 발효에서 효소회수의 모델로 Aspergillus niger를 고체상태로 발효시켜 조사하였다. 발효시킨 밀기울에 서 증류수로 효소추출 효율은 초산 완충액, 구연산 완충액, 구연산-인산 완충액 및 $5 \%$ 메탄올 처리보다 높았다. 따라서, 추출 용매로 증류수를 이용하여 최적 조건을 상세히 검토하였다. 최적 조건은 고체와 액체 용매를 1:5의 비율로 증류수로서 세 번 세척하였을 때에 최대 회수율을 $0.025 \mathrm{U} / \mathrm{g}$ 으로 확보하였다. 